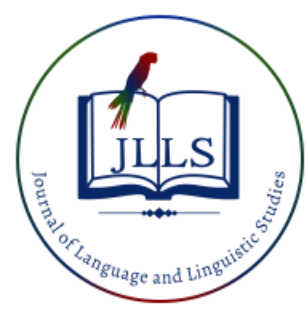

Available online at www.jlls.org

JOURNAL OF LANGUAGE AND LINGUISTIC STUDIES

ISSN: $1305-578 \mathrm{X}$

Journal of Language and Linguistic Studies, 16(4), 1821-1832; 2020

\title{
Evaluating the new English language teaching program of Turkey for primary schools anthropocentrically
}

\author{
Ahmet Erdost Yastıbaş a 1 (iD) \\ Atılım University, Ankara, Turkey
}

\section{APA Citation:}

Yastıbaş, A. E. (2020). Evaluating the new English language teaching program of Turkey for primary schools anthropocentrically. Journal of Language and Linguistic Studies, 16(4), 1821-1832.

Submission Date:12/07/2020

Acceptance Date:28/08/2020

\begin{abstract}
The new geological epoch called the Anthropocene has shown how human activities have influenced the world negatively and revealed the threat created by ongoing human activities to the sustainability of the future of the world. Therefore, what the Anthropocene has shown has to be dealt with. One way to do this is education. Therefore, the present study aimed to evaluate the new Turkish English Language Teaching Program for primary schools anthropocentrically. It was designed as a qualitative study. The data were collected through the new program for primary schools and the coursebooks prepared according to the new program. The data was analyzed through documentation analysis. Triangulation and thick descriptions were used to make the study trustworthy. The findings have shown that the new program has seven themes related to nature in the $2^{\text {nd }}, 3^{\text {rd }}$, and $4^{\text {th }}$-grade syllabi. They have also indicated that these themes can help students to study and learn English in relation to nature. The findings were discussed and suggestions for further studies made.
\end{abstract}

(C) 2020 JLLS and the Authors - Published by JLLS.

Keywords: the Anthropocene; the new English language teaching program; primary schools

\section{Introduction}

The world has entered into a new geographical epoch "the Anthropocene" because of the human effects on the environment (Crutzen, 2006a, 2006b; Lewis \& Maslin, 2015; Steffen, Grinevald, Crutzen, \& McNeill, 2013; Zalasiewicz, Williams, Haywood, \& Ellis, 2011). The Anthropocene indicates how human activities in the world have dominated natural forces and become the most effective and powerful force that has been changing and shaping the world negatively (Crutzen, 2006a, 2006b; Lewis \& Maslin, 2015; Steffen et al., 2013; Zalasiewicz et al., 2011) since the Industrial Revolution (Crutzen, 2006a, p. 13; Steffen et al., 2013). Therefore, the Anthropocene is marked by human footprints on the environment. Human footprints include (a) the increased amount of carbon dioxide (Crutzen, 2006a, 2006b; Steffen et al., 2013; Zalasiewicz et al., 2011), greenhouse gases (Crutzen, 2006a), and nitrogen (Crutzen, 2006b; Lewis \& Maslin, 2015; Steffen et al., 2013); (b) climate change, global warming, and the hole in the ozone layer (Crutzen, 2006a, 2006b; Lewis \& Maslin, 2015; Steffen et al., 2013); (c)

\footnotetext{
${ }^{1}$ Corresponding author.

E-mail address: ahmet.yastibas@atilim.edu.tr
} 
deforestation, use of many water sources, and urbanization (Crutzen, 2006a, 2006b; Steffen et al., 2013); and (d) and the extinction of animals and plants (Crutzen, 2006a, 2006b). Consequently, human activities in the world have damaged the ecology, chemistry, atmosphere, and climate of the world (Crutzen, 2006a).

These human footprints threaten the sustainability of the environment for the future (Crutzen, 2006b), so they have made the Anthropocene a significant problem for people to deal with socially, scientifically, and politically (Zalasiewicz et al., 2011). In other words, these footprints have given people more responsibility for a sustainable future of the world owing to an uncertain future that the Anthropocene has brought in terms of the health of the world (Stratford, 2019). As a result, people are expected to deal with the indicators of the Anthropocene in some ways, one of which is education.

Education should teach students that there is a very close relationship between people and nature and that humanity is a part of nature (Somerville, 2017). Understanding these can enable students to recognize and be aware of the place of the more-than-human-world, which refers to other parts of nature such as animals, insects, and plants in people's lives (Somerville, 2017, pp. 19, 22). Thus, students can learn how they can live with nature in a balanced way (Somerville, 2017; Sterling, 2017; Taylor, 2017). They can also notice that human activities have negative effects on the environment (Sterling, 2017).

Dealing with the Anthropocene with such education requires an inter-disciplinary approach (Carstens, 2016; Leinfelder; 2013; Somerville, 2017). Accordingly, several researchers including Gray and Colluci-Gray (2014), Gilbert (2016), Mahaffy (2014), Pawson, (2015), Stratford (2019), Truong (2017), and Wagler (2011) mentioned that different educational disciplines like chemistry, geography, science, health and physical education, and educational philosophy could be aligned with ecological education to help students to understand the relationship between humans and non-human others.

\subsection{Literature review}

Different scholars have focused on and dealt with the Anthropocene in educating children. It is very significant for the sustainability of the environment because dealing with the Anthropocene makes education ecological, and ecologically educated children can contribute to overcoming environmental problems (Kopnina, 2012). Ritchie (2015) believed that pedagogy could enable children to develop empathy for themselves, other people, and more-than-human others in early childhood education. They can recognize and respect the interdependent and dependent relationship between people and the environment and between people and non-human others (Ritchie, 2015). Therefore, children can learn from what is happening in the entangled life-worlds (Taylor, 2017). Urban environments (Duhn, Malone, \& Tesar, 2017), worms and ants (Taylor \& Pacini-Ketchabaw, 2015), and plants and kangaroos (Taylor, 2017) can be used in educating children. Non-human living beings and urban environments show that children can learn from them and develop different ways of living with them in the world (Duhn et al., 2017; Taylor, 2017; Taylor \& Pacini-Ketchabaw, 2015).

Like chemistry, science, and geography education, English language teaching can also contribute to educating students for ecological purposes. One way to do so is the English language teaching curriculum. It can be designed and developed according to the fact that the Anthropocene has revealed the effects of human activities on the environment. It can also be adjusted and improved according to the same issue. Accordingly, the curriculum studies conducted in Turkey evaluated the English language teaching programs (ELTPs) separately as Bulut and Atabey (2016) and Çiftçi Cinkavuk and Cesur (2018) who evaluated the ELTPs of the $2^{\text {nd }}$ grades and Kurt (2017) who evaluated the ELTP of the $4^{\text {th }}$ grade, or have evaluated the ELTP as a whole as Acar (2018) and Büyükduman (2005) did. Those studies have evaluated the ELTPs according to teachers' and/or students' views in general. Like the national studies, several international English language curriculum studies were conducted by focusing 
on English language teachers in terms of several aspects including their implementation of the curriculum and their place in curriculum development (Alnefaie, 2009; Atai, Babaii, \& Mazlum, 2012; Boghoussi \& El Ouchdi, 2019; Fang \& Garland, 2014; Gherzouli, 2019; Ketabi, Zabihi, \& Ghadiri, 2012; Papajani, 2015; Saad Orafi \& Borg, 2009; Yeh, 2013). Besides, evaluating a country’s English language curriculum in general was studied in other international studies (Ali, 2010; Anastasiadou, 2015; Atai \& Mazlum, 2013; Mappiasse \& Sihes, 2014; Putra, 2014; Sari \& Wardani, 2018; Selvaraj, 2010). English language curriculum was also evaluated in terms of English language learners (Dubetz, 2014; Honboontri, 2014; Madya, 2007) and factors affecting the implementation of the curriculum (Waters \& Viches, 2008).

\subsection{Research questions}

Evaluating an English language curriculum with an anthropocentric perspective was not studied in national and international studies. Therefore, the present study aimed to evaluate the new ELTP for primary schools prepared by the Ministry of National Education (MoNE) in 2018 anthropocentrically. It has answered the research questions below:

1. Does the new ELTP for primary schools include any theme related to nature?

a. If so, what is/are these themes?

2. What are EL students supposed to achieve in the theme(s) related to nature in the new ELTP for primary schools as learning outcomes?

3. How do the $2^{\text {nd }}, 3^{\text {rd }}$, and $4^{\text {th }}$-grade EL coursebooks, which are prepared according to the new ELTP, contextualize and practice nature-related theme(s)?

\section{Method}

\subsection{Research design}

According to Creswell $(2007,2014)$, qualitative research can provide researchers with a detailed and complex understanding of an issue so that researchers can explore the issue. This issue can be social or human (Creswell \& Poth, 2018). Accordingly, the present study was designed as a qualitative study which has aimed to evaluate the ELTP for primary schools by focusing on how the ELTP deals with the Anthropocene which is a human problem. Qualitative research can provide a detailed and complex understanding of how this issue is dealt with in the program.

\subsection{Instruments}

The data were collected through four tools below. The first and second research questions were answered through the first document. The third question was answered through the coursebooks.

1. İngilizce Dersi Öğretim Programı (İlkokul ve Ortaokul 1, 2, 3, 4, 5, 6, 7 ve 8. Sinıflar) [English Language Teaching Program (Primary School and Lower Secondary School $1^{\text {st }}, 2^{\text {nd }}, 3^{\text {rd }}, 4^{\text {th }}, 5^{\text {th }}$, $6^{\text {th }}, 7^{\text {th }}$ and $8^{\text {th }}$ Grades) $]$ (MoNE, 2018),

2. İlkokul İngilizce 2 Ders Kitab1 [Primary School English 2 Coursebook] (Tan, 2019),

3. İlkokul İngilizce 3 Ders Kitabı [Primary School English 3 Coursebook] (Akkabak, Kutlu, Kayıran, Sağlam, \& Karaköse, 2019), and

4. İlkokul İngilizce 4 Ders Kitabı [Primary School English 4 Coursebook] (Tan, 2019). 


\subsection{Data analysis}

The data were documented and analyzed according to what Yıldırım and Şimşek (2013, pp.223-231) suggested to follow as a framework which is composed of five steps: (1) reaching the document, (2) checking originality, (3) understanding the documents, (4) analyzing the documents, and (5) using the analysis. Researchers should use documentation analysis according to their research purposes in the fifth stage.

The researcher reached the ELTP for primary schools on the official website of the MoNE and the printed versions of the English coursebooks for the $2^{\text {nd }}, 3^{\text {rd }}$, and $4^{\text {th }}$ grades, so he ensured that the documents were original. He worked as an English language instructor who prepared his syllabi for some English language courses and used the curricula and syllabi prepared by the departments he worked for in some English language courses. Besides, he received course evaluation and syllabus development courses and researched English language course evaluation. As a result, he could understand the documents. He document-analyzed the new ELTP and coursebooks depending on the literature related to the Anthropocene. The research questions were used to organize and present the results of the analysis.

\subsection{Trustworthiness}

The researcher used two strategies to make this qualitative study trustworthy: (a) thick description (Lincoln \& Guba, 1985, p. 316) and (b) triangulation (Creswell \& Poth, 2018, p. 196). The findings were presented with a thick description to show that the findings reflect what is found out in the documents. Finally, the $2^{\text {nd }}, 3^{\text {rd }}$, and $4^{\text {th }}$-grade English coursebooks were used to triangulate the findings obtained from the new ELTP for primary schools.

\section{Results}

The findings were presented according to the research questions.

R.Q. 1. Does the new ELTP for primary schools include any theme related to nature?

The new ELTP for primary schools has ten themes in the $2^{\text {nd }}, 3^{\text {rd }}$, and $4^{\text {th }}$-grade syllabi. Table 1 below indicates these themes for each grade.

Table 1. Themes in the $2^{\text {nd }}, 3^{\text {rd }}$, and $4^{\text {th }}$-grade syllabi

\begin{tabular}{clll}
\hline Themes & $2^{\text {nd }}$ Grade & $3^{\text {rd }}$ Grade & $4^{\text {th }}$ Grade \\
\hline 1 & Words & Greeting & Classroom rules \\
2 & Friends & My family & Nationality \\
3 & In the classroom & People I love & Cartoon characters \\
4 & Numbers & Feelings & Free time \\
5 & Colors & Toys and games & My day \\
6 & At the playground & My house & Fun with science \\
7 & Body parts & In my city & Jobs \\
8 & Pets & Transportation & My clothes \\
9 & Fruit & Weather & My friends \\
10 & Animals & Nature & Food and drinks \\
\hline
\end{tabular}

As seen in Table 1, themes 8 (pets), 9 (fruit), and 10 (animals) are related to nature in the $2^{\text {nd }}$-grade syllabus. In the $3^{\text {rd }}$-grade syllabus, the themes related to nature are themes 9 (weather) and 10 (nature). Like the $3^{\text {rd }}$-grade syllabus, the $4^{\text {th }}$-grade syllabus has two themes: theme 8 (my clothes where EL students study weather conditions) and 10 (food and drinks). 


\section{R. Q. 2. What are EL students supposed to achieve in the theme(s) related to nature in the new ELTP} for primary schools as learning outcomes?

Theme 8 in the $2^{\text {nd }}$ grade focuses on two language functions: talking about the location of things and making inquiries. In relation to these language functions, $2^{\text {nd }}$ grade EL students are expected to recognize pet animals and to understand and follow simple and brief instructions about the names of pet animals and their locations as the listening learning outcomes. As for the speaking learning outcomes, they are supposed to state the names of pet animals and where they are.

There are three language functions to study and practice in theme 9 in the $2^{\text {nd }}$ grade. They are explaining likes and dislikes, telling someone what they are going to do in a simple way, and giving and responding to simple instructions. According to these language functions, theme 9 aims to enable $2^{\text {nd }}$ grade EL students to identify the names of certain fruit as the listening learning outcome, to express the fruit they like and dislike, and to tell people what to do with fruit as the speaking learning outcomes.

Explaining abilities, likes and dislikes, and making inquires are the language functions focused in theme 10 in the $2^{\text {nd }}$ grade. In relation to these language functions, that $2^{\text {nd }}$ grade EL students can identify certain animal names and understand expressions related to abilities and that they can express the animals they like and dislike and abilities are the learning outcomes of theme 10 .

Theme 9 in the $3^{\text {rd }}$ grade focuses only on one language function: describing the weather. Depending on this language function, $3^{\text {rd }}$ grade EL students are expected to recognize different weather conditions and to talk about different weather conditions in theme 9 . Unlike theme 9 , theme 10 in the $3^{\text {rd }}$ grade focuses on three language functions: Explaining likes and dislikes, making inquiries, and talking about animals and nature. As the listening learning outcome, students are supposed to identify animals' names and nature and follow simple and brief instructions about animals and nature. As the speaking learning outcome, theme 10 aims to enable students to talk about nature and the animals they like and dislike.

Describing the weather, expressing basic needs, making requests, and naming the seasons of the year are the language functions studied in theme 8 in the $4^{\text {th }}$ grade. According to theme $8,4^{\text {th }}$ grade EL students can understand oral texts about weather conditions and clothes and recognize seasons and clothes in such texts. They can talk about weather conditions and seasons and ask and answer questions about the weather conditions and clothing in simple conversations.

Making offers and explaining basic needs and feelings are the language functions studied in theme 10 in the $4^{\text {th }}$ grade. Depending on these language functions, theme 10 expects EL students to express their basic needs and feelings as well as other people's basic needs and feelings as the speaking learning outcomes. It also expects them to identify words and phrases related to food and drinks, the offers about their basic needs, and other people's basic needs and feelings as the listening learning outcomes.

\section{R. Q. 3. How do the $2^{\text {nd }}, 3^{\text {rd }}$, and $4^{\text {th }}$-grade EL coursebooks, which are prepared according to the new ELTP contextualize and practice nature-related theme(s)?}

The new ELTP for primary schools aims to improve two skills in the $2^{\text {nd }}, 3^{\text {rd }}$, and $4^{\text {th }}$ grades: listening and speaking. Therefore, the $2^{\text {nd }}, 3^{\text {rd }}$, and $4^{\text {th }}$-grade EL coursebooks generally include listening and speaking activities. In theme 8 in the $2^{\text {nd }}$ grade, the target words are "bird, parrot, fish, cat, frog, dog, rabbit, and turtle" (Tan, 2019, p. 108). $2^{\text {nd }}$ grade EL students can study English through various listening activities in which these pet animals are used and which can help them to talk about the locations of pet animals. To exemplify, there is a mouse in the first listening activity, a cat, a dog, and birds in the second activity, a rabbit and a turtle in the third activity, and a bird, a dog, and a cat in the fourth activity. These animals are included in the listening activities to explain the locations of pet animals to students. Students are given different tasks in these activities, such as repeating, following, and answering questions. These pet animals are also used in speaking activities. For instance, they are expected to make 
sentences about several pet animals, including cat, dog, and rabbit and talk about the locations of different pets by asking questions with where to each other in a dialogue.

In theme 9 in the $2^{\text {nd }}$ grade, "fresh fruit, apple, banana, orange, peach, grapes, cherry, lemon, strawberry, and melon" are the target words (Tan, 2019, p. 122). EL students can study and practice three language functions (expressing their likes and dislikes, giving and responding to simple instructions, and telling people what to do) through listening and speaking activities which were designed and developed based on fruit. In the first, second, and fourth listening activities, a boy and a girl talk about the fruit they like and dislike. In the third activity, four people talk about the fruit they like and dislike, and the fifth listening activity includes simple instructions such as cut the melon. Students are given different tasks such as following, choosing, and completing in each listening activity. In speaking, students act out two dialogues: one about the fruit they like and dislike and the other one about telling people what to do with fruit. In addition, there are sentence completion activities in which students are supposed to draw which fruit a boy and a girl like and dislike, to look at different pictures about two girls and one boy who talks about the fruit they like and dislike, and to draw their favorite fruit. In all of these activities, the target words related to fruit are used.

Theme 10 in the $2^{\text {nd }}$ grade aims to teach three language functions: expressing abilities, expressing likes and dislikes, and making simple inquires. "Cow, donkey, horse, duck, goat, lion, elephant, monkey, snake, and spider" are used to study and practice these language functions (Tan, 2019, p. 136). In listening, students are expected to listen to and follow three children who show each other three animal puppets and what different animals including a bird, a monkey, and a horse can do. They are also supposed to listen and tick what different animals (a monkey, a snake, a fish, and a horse) can do. In speaking, they are expected to talk about the abilities of five animals in the picture. Besides speaking and listening activities, theme 10 also has a reading passage in which two boys and two girls talk about the animals they like and dislike.

The language function that is studied and practiced in theme 8 in the $3^{\text {rd }}$ grade is describing the weather. Students are expected to learn "sunny, rainy, snowy, windy, cloudy, freezing, cold, hot, warm, nice, and wet" as target words in theme 8 (Akkabak et al., 2019). Theme 8 starts with a writing activity where students write weather conditions in the pictures. It goes on with a matching activity where students match the sentences with the pictures. In listening, a dialogue between Betty and Sinan who talk about and compare weather conditions in Bodrum and London and conversations about different weather conditions in pictures are included in listening activities. In speaking activities, students talk about weather conditions according to the pictures, in different environmental places such as dessert and pole, and in ten cities of Turkey. During these activities, they are supposed to ask and answer questions such as "how is the weather in X" and "is the weather rainy in X" ( $\mathrm{x}$ can be a city or an environmental place). There is a reading passage about the weather conditions in different Turkish cities and what people should wear in different weather conditions.

Theme 10 in the $3^{\text {rd }}$ grade aims to enable students to study and practice three language functions: expressing likes and dislikes, making simple inquiries, and talking about nature and animals. In relation to these language functions, students are supposed to learn "forest, bear, dolphin, fish, sea, pigeon, bee, mountain, butterfly, frog, ladybird, whale, shark, chicken, cow, donkey, duck, snake, goat, horse, lion, monkey, and elephant" (Akkabak et al., 2019, pp. 160-162). Theme 10 includes matching and choosing activities related to animals in the beginning. In listening, students listen to (a) sentences with there is and there are about the number of the animals in the pictures, (b) sentences about which animals people like and dislike, (c) a dialogue between two boys who talk about the number of the animals in the aquarium and whether they like or dislike them, (d) a dialogue between one boy and one girl who talk about animals in terms of their numbers, colors, size, and whether they like those animals or not, and (e) sentences about the animals people like and dislike. In the dialogues, students are also expected to 
act the dialogues out. In speaking, students ask and answer questions with there is and there are about the animals in two pictures. They also talk about animals by introducing them, giving information about their colors, sizes, and abilities, and saying whether they like or dislike them. There is a reading activity similar to this speaking activity.

Students study and practice describing the weather, expressing their basic needs, and naming the seasons of the year in theme 8 in the $4^{\text {th }}$ grade. Target words related to these language functions are "hot, umbrella, coat, trousers, skirt, jacket, dress, socks, shirt, t-shirt, boots, and shoes" to explain their basic needs (Tan, 2019, p. 108) and "cold, snowy, warm, cloudy, hot, sunny, cool, and rainy" to describe the weather (Tan, 2019, p. 110). In listening, students listen to weather conditions in four seasons and in pictures to repeat and choose true or false in order. Besides, they listen to a telephone conversation about weather conditions in seasons and which clothes should be worn for a fill-in-the-blank activity. In speaking, students talk about different weather conditions in seasons by asking and answering the questions "what the weather is like in spring" and "what season it is." They also do a matching activity where they match weather conditions and clothes, play a guessing game about weather conditions and what to wear, and classify the clothes in a seasonal weather chart.

Theme 10 in the $4^{\text {th }}$ grade focuses on making offers and expressing basic needs and feelings. In relation to these language functions, students listen to (a) what two boys order in a restaurant, (b) which food and drinks belong to a mouse and a cat, (c) what is in Patty's tray, (d) which food and drinks people like and dislike, and (e) what three people want. They are given different tasks such as following, writing, completing, and matching in these listening texts. In speaking, they act out two dialogues about food and drinks. In the dialogues, they are supposed to talk about what they want to drink and/or eat by asking and answering questions including "would you like some cheese," "want an apple," "do you want some water," and "what about some chocolate."

\section{Discussion}

The new ELTP of Turkey for primary schools can respond to the call for interdisciplinary education mentioned by Carstens (2016), Leinfelder (2013), and Somerville (2017) to deal with what the Anthropocene has revealed about the negative effects of human activities on the world as it was suggested in different disciplines (Gray \& Colluci-Gray, 2014; Gilbert, 2016; Mahaffy, 2014; Pawson, 2015; Stratford, 2019; Truong, 2017; Wagler, 2011). The new ELTP can enable students in the $2^{\text {nd }}, 3^{\text {rd }}$, and $4^{\text {th }}$ grades to study and learn English through some themes related to nature.

$2^{\text {nd }}$ grade English language students are supposed to make simple inquires and talk about the location of things in English in theme 8. Accordingly, its listening and speaking learning outcomes are prepared depending on nature. Besides, the theme is contextualized in terms of pet animals. All of the activities in the theme are also integrated with pet animals and require students to practice language functions through pet animals. Therefore, the theme can enable students to study and practice these language functions and to achieve learning outcomes in relation to nature.

Like theme 8, $2^{\text {nd }}$ grade English language students are expected to express their likes and dislikes, to give and respond to simple instructions, and tell a person what to do in English theme 9. The speaking and listening learning outcomes related to these language functions are formed by being integrated with nature because the context of the theme is based on fruit, and every activity in the theme is related to fruit. Thus, students can express their likes and dislikes, give and respond to simple instructions, and tell a person what to do by focusing on fruit.

Similarly, theme 10 can enable $2^{\text {nd }}$ grade students to express abilities, likes and dislikes and to make simple inquires by studying and practicing these functions in relation to nature because the basis of its 
contextualization and practice is animals. Students can study and practice these functions through animals, so they are expected to achieve speaking and listening learning outcomes, which are worded by being related to animals.

Unlike the themes in the $2^{\text {nd }}$ grade, the themes in the $3^{\text {rd }}$ grade have language functions directly related to nature. Theme 9 aims to help $3^{\text {rd }}$ grade English language students to describe the weather. Therefore, all of its learning objectives and activities are contextualized based on weather conditions. Thus, students can study and learn English in relation to weather conditions.

Expressing likes and dislikes, making simple inquiries, and talking about nature and animals are the language functions focused on by theme 10 of the $3^{\text {rd }}$ grade. Listening and speaking learning outcomes are determined and prepared depending on nature because the theme is contextualized in terms of nature and animals. Therefore, students need to study and practice these language goals through the activities related to this contextualization, so they can express their likes and dislikes and make simple inquires in relation to nature and animals.

Like themes 9 and 10 of the $3^{\text {rd }}$ grade, theme 8 of $4^{\text {th }}$ grade has nature-related language functions. Students are expected to describe the weather, express their basic needs in different weather conditions, and name the seasons of a year. In addition to these functions, they are expected to make simple requests. Speaking and listening learning outcomes are prepared based on weather conditions according to these language functions. Accordingly, the theme is contextualized in terms of weather conditions, and the activities are related to them. Besides, the theme shows students how different weather conditions affect the way people wear. Consequently, students can study and learn English through weather conditions and understand how nature may affect their lives through the effects of weather conditions on clothing.

Theme 10 of the $4^{\text {th }}$ grade can enable students to make offers and simple inquires and to express their basic needs and feelings through a concept related to nature because its contextualization is based on food and drinks. Thus, its speaking and listening learning outcomes and activities are prepared and developed in accordance with food and drinks. Therefore, students can learn English by studying and practicing language functions in relation to food and drinks.

All of these themes show that nature can be used to teach English to young English language students as stated in the literature (Duhn et al., 2017; Taylor, 2017; Taylor \& Pacini-Ketchabaw, 2015). According to Duhn et al. (2017), Taylor (2017), and Taylor and Pacini-Ketchabaw (2015), children can also learn from non-human others. Similarly, these themes also indicate that students can learn English from non-human others. Studying and learning English through themes related to nature can enable young English language students to develop empathy for the environment as Ritchie (2015) stated.

\section{Conclusions}

The Anthropocene has revealed the destructive effects of human activities on nature and the threat created by the ongoing negative human activities in the environment on the sustainability of the future of the world. Therefore, it has to be taken seriously. One way to deal with what the Anthropocene has revealed is education. Accordingly, the present study has aimed to evaluate the new Turkish ELTP for primary schools anthropocentrically. The findings have showed that it could respond to what the Anthropocene has caused through different themes related to nature in the $2^{\text {nd }}, 3^{\text {rd }}$, and $4^{\text {th }}$ grades. These themes can help young English language students to study and learn English in relation to nature.

Further studies can be made to evaluate the existing English language teaching curriculum or curricula for different stages of education and the existing syllabus or syllabi of several English language courses. Similarly, English language coursebooks can be evaluated in future research. The data obtained 
can help English language teachers, curriculum and/or syllabus developers, and coursebook writers to identify the strengths and weaknesses of their curriculum, syllabus, and/or coursebooks in terms of the Anthropocene so that they can improve their materials. Such studies can help to make English language teaching more ecological and raise English language students' awareness of the relationship between people and nature so that such studies can contribute to the sustainable future of the world.

\section{Ethics Committee Approval}

The author(s) confirm(s) that the study does not need ethics committee approval according to the research integrity rules in their country (Date of Confirmation: December 11, 2020).

\section{References}

Acar, A. (2018). A comparison of the 2013 and 2018 primary and secondary schools ELT curricula in Turkey: An analysis of $7^{\text {th }}$-grade syllabi. Milli Eğitim, 48(224), 299-325.

Akkabak, F., Kutlu, M. Z., Kayıran, M. T., Sağlam, P., \& Karaköse, S. (2019). Illkokul İngilizce 3 ders kitabı. Ankara: Milli Eğitim Bakanlığı Yayınları.

Ali, M. M. (2010). Revisiting English language teaching (ELT) curriculum design: How appropriate is Bangladesh higher secondary level national ELT curriculum as a learner-centred one? IIUC Studies, 7, 283-296.

Alnefaie, S. K. (2016). Teachers' role in the development of EFL curriculum in Saudi Arabia: The marginalized status. Cogent Education, 3, 1-14.

Anastasiadou, A. (2015). EFL curriculum design: The case of the Greek state school reality in the last two decades (1997-2014). International Journal of Applied Linguistics \& English Literature, 4(2), 112-119.

Atai, M. R. \& Mazlum, F. (2013). English language teaching curriculum in Iran: Planning and practice. The Curriculum Journal, 24(3), 389-411.

Atai, M. R., Babaii, E., \& Mazlum, F. (2012). Mainstream ELT curriculum implementation in Iran: A micro analysis perspective. TELL, 6(2), 1-23.

Baghoussi, M. \& El Ouchdi, I. Z. (2019). The implementation of the project-based learning approach in the Algerian EFL context: Curriculum designers' expectations and teachers' obstacles. Arab World English Journal, 10(1), 271-282.

Bulut, İ. \& Atabey, E. (2016). An evaluation of the effectiveness of the primary school $2^{\text {nd }}$ grade English language curriculum in practice. İn̈̈n̈ University Journal of the Faculty of Education, 17(3), 257280 .

Büyükduman, F. İ. (2005). İlköğretim okulları İngilizce öğretmenlerinin birinci kademe İngilizce öğretim programına ilişkin görüşleri [The opinions of elementary school English teachers on the English curriculum for elementary schools]. Hacettepe Üniversitesi Eğitim Fakültesi Dergisi, 28, 55-64.

Cartens, D. (2016). The Anthropocene crisis and higher education: A fundamental shift. South African Journal of Higher Education, 30(3), 255-273. 
Çiftçi Cinkavuk, E. \& Cesur, K. (2018). An evaluation of second grade English language teaching program of primary school: Tokat case. Erzincan Üniversitesi Eğitim Fakültesi Dergisi, 20(3), 749766.

Creswell, J. W. (2007). Qualitative inquiry \& research design: Choosing among five approaches ( $2^{\text {nd }}$ ed.). Thousand Oaks, California, the United States of America: Sage Publications.

Creswell, J. W. (2014). Research design: Qualitative, quantitative, and mixed methods approaches (4 ${ }^{\text {th }}$ ed.). Thousand Oaks, California, the United States of America: Sage Publications Inc.

Creswell, J. W., \& Poth, C. N. (2018). Qualitative inquiry \& research design: Choosing among five approaches $\left(4^{\text {th }}\right.$ ed.). Thousand Oaks, California, the United States of America: Sage Publications Inc.

Crutzen, P. J. (2006a). The “Anthropocene”. In E. Ehlers \& T. Krafft (Eds.), Earth system science in the Anthropocene (pp. 13-18). Springer.

Crutzen, P. J. (2006b). The Anthropocene: The current human-dominated geological era. Retrieved from www.pas.va/content/dam/accademia/pdf/acta18/acta18-crutzen.pdf

Dubetz, N. E. (2014). Studying the effects of an EFL curriculum for young adults in Brazil. English Language Teaching, 7(1), 103-112.

Duhn, I., Malone, K., \& Tesar, M. (2017). Troubling the intersections of urban/nature/childhood in environmental education. Environmental Education Research, 23(10), 1357-1368.

Fang, X. \& Garland, P. (2014). Teacher orientation to ELT curriculum reform: An ethnographic study in a Chinese secondary school. Asia-Pacific Education Researcher, 23(2), 311-319.

Gherzouli, I. (2019). Towards a democratic Algerian curriculum development through secondary EFL teachers' involvement. International Journal of Curriculum and Instruction, 11(1), 1-22.

Gilbert, J. (2016). Transforming science education for the Anthropocene - is it possible? Research in Science Education, 46, 187-201.

Gray, D. \& Colucci-Gray, L. (2014). Globalisation and the Anthropocene: The reconfiguration of science education for a sustainable future. Sisyphus Journal of Education, 2(3), 14-31.

Hongboontri, C. (2014). Practical curriculum inquiry: Students' voices of their EFL curriculum and instruction. Australian Journal of Teacher Education, 39(11), 65-81.

Ketabi, S., Zabihi, R., \& Ghadiri, M. (2012). Critical thinking across the ELT curriculum: A mixed methods approach to analyzing L2 teachers' attitudes toward critical thinking instruction. International Journal of Research Studies in Education, 2(3), 15-24.

Kopnina, H. (2012). Education for sustainable development (ESD): The turn away from 'environment' in the environmental education? Environmental Education Research, 18(5), 699-717.

Kurt, A. (2017). 4. sınıf İngilizce dersi öğretim programının bağlami girdi, süreç, ürün modeline göre değerlendirilmesi. Dicle Üniversitesi Ziya Gökalp Eğitim Fakültesi Dergisi, 30, 508-524.

Leinfelder, R. (2013). Anthropocene: Envisioning the future age of humans. RCC Perspectives, 3, 9-28.

Lewis, S. L. \& Maslin, M. A. (2015). Defining the Anthropocene. Nature, 519, 171-180.

Lincoln, Y. S. \& Guba, E. G. (1985). Naturalistic inquiry. Newbury Park, CA: Sage Publications.

Madya, S. (2007). Searching for an appropriate EFL curriculum design for the Indonesian pluralistic society. TEFLIN Journal, 18(2), 196-221. 
Mahaffy, P. G. (2014). Telling time: Chemistry education in the Anthropocene epoch. Journal of Chemical Education, 91, 463-465.

Mappiasse, S. S. \& Sihes, A. J. B. (2014). Evaluation of English as a foreign language and its curriculum in Indonesia: A review. English Language Teaching, 7(1), 113-121.

Milli Eğitim Bakanlığı [Ministry of National Education]. (2018). Ingilizce dersi öğretim programı (ilkokul ve ortaokul 1, 2, 3, 4, 5, 6, 7 ve 8. siniflar) [English language teaching program (primary school and lower secondary school $1^{\text {st }}, 2^{\text {nd }}, 3^{\text {rd }}, 4^{\text {th }}, 5^{\text {th }}, 6^{\text {th }}, 7^{\text {th }}$ and $8^{\text {th }}$ grades) $]$. Retrieved from http://mufredat.meb.gov.tr/Dosyalar/201812411191321\%C4\%BONG\%C4\%BOL\%C4\%BOZCE\%20\%C3\%96\%C4\%9ERET\%C4\%B0 M\%20PROGRAMI\%20Klas\%C3\%B6r\%C3\%BC.pdf

Orafi, S. M. S. \& Borg, S. (2009). Intentions and realities in implementing communicative curriculum reform. System, 37, 243-253.

Papajani, J. (2015). Reshaping the EFL curriculum in Albania - main factors coming from the high schools of Elbasan. European Scientific Journal, 2, 1-11.

Pawson, E. (2015). What sort of geographical education for the Anthropocene? Geographical Research, 53(3), 306-312.

Putra, K. A. (2014). The implication of curriculum renewal on ELT in Indonesia. Parole, 4(1), 63-75.

Ritchie, J. (2015). Social, cultural, and ecological justice in the age of the Anthropocene: A New Zealand early childhood care and education perspective. Journal of Pedagogy, 2, 41-56.

Sari, S. N. W. \& Wardani, N. A. K. (2018). An analysis of Indonesia's 2013 EFL curriculum and Turkey's national English language curriculum for secondary schools. Indonesian Journal of English Language Teaching and Applied Linguistics, 3(1), 23-37.

Selveraj, B. (2010). English language teaching (ELT) curriculum reforms in Malaysia. Voice of Academia, 5(1), 51-60.

Somerville, M. (2017). The Anthropocene's call to educational research. In K. Malone, S. Truong, \& T. Gray (Eds.), Reimagining sustainability in precarious times (pp. 17-28). Springer.

Steffen, W., Grinevald, J., Crutzen, P., \& McNeill, J. (2011). The Anthropocene: Conceptual and historical perspectives. Philosophical Transactions of the Royal Society A, 369, 842-867.

Sterling, S. (2017). Assuming the future: Repurposing education in a volatile age. In B. Jickling \& S. Sterling (Eds.), Post-sustainability and environmental education (pp. 31-45). Palgrave.

Stratford, R. (2019). Educational philosophy, ecology, and the Anthropocene. Educational Philosophy and Theory, 51(2), 149-152.

Tan, F. (2019). Illkokul İngilizce 2 ders kitabı. Ankara: Bilim Yayın Kültür Limited Şirketi.

Tan, F. (2019). Illkokul İngilizce 4 ders kitabı. İstanbul: FCM Yayıncılık.

Taylor, A. (2017). Beyond stewardship: Common world pedagogies for the Anthropocene. Environmental Education Research, 23(10), 1448-1461.

Taylor, A. \& Pacini-Ketchabaw, V. (2015). Learning with children, ants, and worms in the Anthropocene: Towards a common world pedagogy of multispecies. Pedagogy, Culture \& Society, 23(4), 507-529.

Truong, S. (2017). Expanding curriculum pathways between education for sustainability (EfS) and health and physical education (HPE). In K. Malone, S. Truong, \& T. Gray (Eds.), Reimagining sustainability in precarious times (pp. 239-251). Springer. 
Wagler, R. (2011). The Anthropocene mass extinction: An emerging curriculum theme for science educators. The American Biology Teacher, 73(2), 78-83.

Waters, A. \& Vilches, M. L. C. (2008). Factors affecting ELT reforms: The case of the Philippines basic education reform. RELC, 39(1), 5-24.

Yeh, H.-C. (2013). English curriculum redesign through an EFL teacher study group. Taiwan Journal of TESOL, 10(1), 1-35.

Yıldırım, A. \& Şimşek, H. (2013). Sosyal bilimlerde nitel araştırma yöntemleri ( $9^{\text {th }}$ ed.). Ankara: Seçkin Yayıncilik.

Zalasiewicz, J., Williams, M., Haywood, A., \& Ellis, M. (2011). The Anthropocene: A new epoch of geological time? Philosophical Transactions of the Royal Society A, 369, 835-841.

\section{Türkiye'nin ilkokullar için olan yeni İngilizce öğretim programını antroposentrik bir açıdan değerlendirme}

\section{$\ddot{O} \mathbf{z}$}

Antroposen olarak adlandırılan yeni bir jeolojik çağ, insan aktivitelerinin dünyayı nasıl olumsuz etkilediğini göstermiş ve dünyanın geleceğinin sürdürülebilirliği için devam eden için aktivitelerinin oluşturduğu tehdidi ortaya çıkarmıştır. Bu nedenle Antroposenin gösterdikleriyle ilgilenilmelidir. Bunu yapmanın yollarından bir tanesi eğitimdir. Bu yüzden, bu çalışma ilkokullar için olan yeni Türk İngilizce Öğretim Programını antroposen bir açıdan değerlendirmeyi amaçlamıştır. Nitel bir çalışma olarak tasarlanmıştır. Veriler, ilkokul için hazırlanan yeni program ve bu yeni programa göre hazırlanan ders kitaplarından toplanmıştır. Veriler, doküman incelemesi ile analiz edilmiştir. Veri çeşitlemesi ve yoğun anlatım çalışmayı inandırıcı kılmak için kullanılmıştır. Bulgular, yeni programın 2., 3. ve 4. sınıf ders izlencelerinde yedi tane doğayla ilgili temanın olduğunu göstermektedir. Ayrıca, bulgular, bu temaların öğrencilerin İngilizceyi doğayla ilişkili olarak çalışmalarına ve öğrenmelerine yardımcı olduğunu göstermektedir. Bulgular tartışılmış ve gelecekteki çalışmalar için önerilerde bulunulmuştur.

Anahtar sözcükler: Antroposen; yeni İngilizce öğretim programı; ilkokullar

\section{AUTHOR BIODATA}

Ahmet Erdost YASTIBAŞ has been working as an English language instructor and teaching English for academic, general, and occupational purposes courses. He has a Ph.D. degree in English language teaching. His research interests include language assessment and evaluation, language program evaluation, and technology-enhanced language teaching. 